\title{
Pembinaan Konsep Kendiri dari Perspektif Barat dan Islam
}

\author{
Siti Jamiaah Abdul Jalil \\ Universiti Malaya, sitijamiaah82@gmail.com \\ Yusmini Md Yusoff \\ Universiti Malaya, yusmini@um.edu.my \\ Rozmi Ismail \\ Universiti Kebangsaan Malaysia, rozmi@ukm.edu.my
}

\begin{abstract}
Abstrak
Konsep kendiri ialah persepsi individu terhadap nilai dirinya. Konsep kendiri adalah istilah yang diperkenalkan oleh Barat dan dianggap sebagai pusat konsep utama dalam ilmu psikologi. Ini kerana melaluinya boleh memahami tingkah laku manusia yang menjadi matlamat utama dalam ilmu psikologi. Walaupun, konsep kendiri tidak dibincangkan secara khusus dalam Islam, namun, terdapat perbincangan secara konsep berkaitan dengannya. Oleh itu, objektif penulisan ini ialah untuk mengetahui elemen-elemen pembinaan konsep kendiri positif dari perspektif Barat dan Islam,serta mengenal pasti persamaan dan perbezaan dua perspektif ini terhadap pembinaan konsep kendiri. Hasil mendapati terdapat 3 elemen yang mempengaruhi konsep kendiri seseorang iaitu daripada (1) persepsi individu terhadap dirinya sendiri, (2) penilaian orang lain terhadap dirinya dan (3) penilaiannya terhadap persepsi orang lain kepada dirinya. Walau bagaimanapun, Islam mempunyai elemen tambahan iaitu penilaian terhadap pandangan Pencipta terhadap dirinya. Kajian juga mendapati mengutamakan pandangan Allah dalam setiap perkara dengan menjauhi larangan-Nya dan melakukan suruhan-Nya mampu mengurangkan pengaruh 3 elemen tersebut.
\end{abstract}

Kata kunci: konsep kendiri, psikologi, perspektif Islam, sifat mahmudah

\section{The Construction of Self-Concept from the Perspectives of the West and Islam}

\begin{abstract}
Self-concept is the individual's perception of the value itself. Self-concept is a term introduced by western and it is considered the most central concept in psychology. Through it we can understand human behaviour which is the main goal in psychology. Although, the self-concept was not discussed specifically in Islam, however, there are discussions related concepts in Islam. Therefore, the objective of this article is to identify the elements of construction of a positive self-concept of the West and Islamic perspective and to identify the similarities and differences
\end{abstract}


between these two perspectives on building self-concept. The results found that there were three elements that affect a person's self-concept. That is from (1) the individual's perception of themselves, (2) the judgment of others against him and (3) evaluation of the perception of others to himself. However, Islam has one additional element, namely the assessment of the Creator's view of himself. Prefer sight of God in everything by staying away from His ban and do His errands can reduce the influence of these three elements.

Keywords: self-concept, psychology, Islam perspective, mahmudah characteristics

\section{Pendahuluan}

Encyclopedia of Applied Psychology mendefinisikan konsep kendiri sebagai pegangan kepercayaan seseorang tentang kualiti dirinya dan bagaimana dia menilai kualiti tersebut. ${ }^{1}$ Shavelson dan Bolus pula menjelaskan konsep kendiri sebagai tanggapan seseorang terhadap dirinya. ${ }^{2}$ Tanggapan yang dimaksudkan meliputi kepercayaan, perasaan, sikap harga diri dan juga nilai. ${ }^{3}$ Ia merupakan penilaian diri yang diperoleh berdasarkan pengalaman kehidupan yang dilalui. Azizi Yahya dan rakan-rakan menghuraikan konsep kendiri sebagai penilaian seseorang terhadap dirinya sendiri atau bagaimana ia menanggapi dirinya sendiri, sama ada secara positif atau negatif. ${ }^{4}$ Begitu juga dengan definisi yang diberikan oleh Habibah \& Noran, konsep kendiri sebagai penilaian seseorang ke atas dirinya sendiri atau bagaimana ia menganggap tentang dirinya sama ada secara positif atau negatif. Menurutnya lagi, konsep kendiri seseorang meliputi persepsi tentang diri dan alam sekelilingnya melalui derianya dan juga perasaan tentang kebolehannya yang meliputi keyakinan dan harga dirinya. ${ }^{5}$

1 Charles Donald Spielberger, Encyclopedia of Applied Psychology (USA: Imprint: Academic Press, 2004), 483.

2 Ricahard J. Shavelson, \& R. Bolus, "Self-Concept: The Interplay of Theory and Method," Journal of Educational Psychology 74, (1982): 3-17.

3 Mohd. Salleh Lebar, Asas Psikologi Perkembangan (Kuala Lumpur: Utusan Publication \& Distributors Sdn. Bhd, 1994), 185.

4 Azizi Yahaya, Fawziah Yahya, Zurihanmi Zakaria \& Noordin Yahaya, Pembangunan Kendiri (Johor: UTM, 2005), 2.

5 Habibah Elias \& Noran Fauziah Yaakub, Psikologi Personaliti (Kuala Lumpur: Dewan Bahasa dan Pustaka, 2006), 98. 
Individu yang memiliki konsep kendiri positif pada kebiasaannya senang didampingi dan mudah untuk berinteraksi dengan orang lain. Mereka selalu mendapat layanan baik daripada orang di sekeliling mereka sama ada daripada keluarga, rakanrakan dan jiran tetangga. Selain itu, mereka memiliki banyak ciriciri personaliti yang baik seperti bersifat optimis, bersikap lebih terbuka dan mudah menerima pendapat mahupun kritikan orang lain. Mereka juga berperwatakan tenang dan sering berasa gembira serta memiliki keyakinan terhadap diri dan tidak mudah putus asa dalam menghadapi cabaran. Pencapaian hidup mereka juga memberangsangkan kerana sentiasa mendapat lebih kejayaan berbanding kegagalan. Jika berlaku kegagalan, mereka akan menerima dengan tabah serta tidak mudah mengalah. ${ }^{6}$

Konsep kendiri negatif pula biasanya dikaitkan dengan individu yang sering menghadapi kegagalan sama ada dari sudut pencapaian hidup mahupun hubungan dengan orang lain. Mereka biasanya kurang mendapat kasih sayang dan prihatin daripada orang sekeliling seperti ibu bapa, keluarga dan rakan-rakan. Mereka sering dimarahi, dikritik atau dipermainkan oleh orang lain. Ini mengakibatkan mereka sering berasa tidak berpuas hati, tidak gembira, kurang keyakinan diri, mudah tersinggung, muram dan menjadi seorang yang pasif. Melalui hubungan sosial, mereka tidak mudah bergaul dengan orang lain dan lebih suka bergaul dengan yang lebih muda dan mempunyai keintelektualan yang rendah. Lazimnya, kerja-kerja yang mudah dan senang menjadi pilihan mereka bagi menjamin kejayaan. ${ }^{7}$

Oleh itu, konsep kendiri mempunyai peranan yang besar dalam menentukan tingkah laku seseorang. Menurut Wells, konsep kendiri adalah ejen kepada penyebab berlakunya sesuatu tingkah laku. ${ }^{8}$ Malah, konsep kendiri juga merupakan kunci bagi mengintegrasikan personaliti dalam memotivasikan tingkah laku. ${ }^{9}$ Ini dikuatkan oleh Lecky yang menyatakan konsep kendiri sebagai

Azizi Yahaya et. al, Pembangunan Kendiri, 33.

Azizi Yahaya et. al, Pembangunan Kendiri, 34-35.

L. E. Wells, "Theories of Deviance and the Self-Concept," Social Psychology 41:3 (1978):184-204.

9 R. B. Burns, The Self Concept: Theory, Measurement, Development and Behaviour (New York: Longman, 1979), 2. 
nukleus kepada personaliti. ${ }^{10}$ Selari dengan Rogers yang menganggap konsep kendiri sebagai asas kepada pembentukan personaliti seseorang. ${ }^{11}$ Oleh kerana itulah, konsep kendiri menjadi fokus perbincangan ahli psikologi kerana ia merupakan pusat konsep utama (most central concept) dalam ilmu psikologi dan melaluinya kita boleh memahami tingkah laku manusia. ${ }^{12}$

Kesimpulannya, konsep kendiri merupakan penilaian, persepsi atau tanggapan individu terhadap diri sendiri yang meliputi kepercayaan, sikap, nilai dan perasaannya. Penilaian, persepsi atau tanggapan terhadap diri yang diperoleh daripada pengalaman yang dilalui dan alam sekeliling boleh berlaku dalam bentuk positif mahupun negatif. Dari kedua-dua jenis konsep kendiri tersebut, konsep kendiri positif merupakan matlamat dalam pembinaan dan pembentukan peribadi manusia.

\section{Pembinaan Konsep Kendiri dari Perspektif Barat}

Konsep kendiri (self-concept) ialah istilah yang digunakan dalam ilmu psikologi Barat yang pada mulanya lebih popular dengan istilah 'diri'. Perkataan konsep ini diperkenalkan oleh ahli psikologi kerana mempunyai perkaitan dengan keperluannya terhadap pemikiran manusia. ${ }^{13}$ Walaupun perkataan konsep kendiri hanya mula digunakan pada awal abad ke-20, namun, teori diri telah lama diperbincangkan oleh ahli-ahli falsafah dan ahli psikologi Barat. Antara ahli psikologi yang memperkenalkan teori diri ialah Carl Rogers. Beliau mendefinisikan kendiri (self) sebagai:

${ }^{10}$ Prescott Lecky, Self Consistency, dlm. Burns, R. B., The Self Concept: Theory, Measurement, Development and Behaviour (New York: Longman, 1979), 2.

11 Rohany Nasir \& Fatimah Omar, "Burnout dan Konsep Kendiri Kerjaya di Kalangan Pegawai Kebajikan Masyarakat," ed. Rohany Nasir \& Fatimah Omar, Kesejahteraan Manusia: Perspektif Psikologi (Bangi: UKM, 2006), 113-126.

12 S. Epstein, "The Self-Concept Revisited or a Theory of a Theory," American Psychologist, (May 1973): 404-416.

13 Burns, The Self Concept: Theory, Measurement, Development and Behaviour, 65. 
an organized fluid, but consistent conceptual pattern of perceptions of characteristics and relationships of the 'I' or the 'me', together with values attached to these concepts. ${ }^{14}$

Pada mulanya, 'diri' disamakan dengan konsep metafizik sebagai jiwa (soul), hati (will) dan semangat (spirit). Namun, bagi mereka perbincangan tentang 'diri' telah terbenam dalam kekusutan falsafah dan dogma agama. Hal ini kerana perbincangan mengenainya rumit dan terlalu panjang. Kemudian, pada akhirakhir abad ke-19, perbincangannya diteruskan dengan lebih tersusun dan bersistematik tanpa mengaitkannya dengan unsur keagamaan oleh ahli-ahli psikologi. ${ }^{15}$

William James antara ahli psikologi yang terawal membincangkan konsep diri dengan lebih mendalam. Beliau mengemukakan empat komponen dalam diri yang memberi kesan kepada keyakinan diri iaitu (1) diri spiritual, (2) diri material, (3) diri sosial dan (4) diri jasad. ${ }^{16}$ Diri spiritual berkait dengan emosi dan keinginan individu. Diri material ialah lanjutan diri yang terkandung sebagai tambahan kepada jasad individu itu sendiri, keluarga dan harta miliknya. Diri sosial berkait dengan pandangan orang lain terhadap individu tersebut dan diri jasad pula berkait dengan imej badan atau anggota badan. ${ }^{17}$ James menjelaskan konsep kendiri mempunyai kaitan dengan apa yang diketahui dan difahami oleh seseorang individu berkaitan dirinya yang merangkumi jasad luarannya, keluarga, harta yang dimilikinya, emosi, keinginannya serta pandangan orang lain terhadap dirinya. Menurut beliau, empat elemen diri ini bergabung dalam cara yang unik untuk membentuk pandangan setiap orang terhadap dirinya sendiri dan dalam banyak aspek ia tidak mudah untuk dipisahkan dalam membentuk konsep kendiri.

Berlainan pula dengan Freud, yang mengemukakan tiga elemen iaitu id, ego dan super ego yang menjadi kerangka konsep

14 Rogers, C. R., Client-centered Therapy (New York: Houghton Mifflin, 1951), 498.

15 Burns, The Self Concept: Theory, Measurement, Development and Behaviour, 5.

16 William James, Principles of Psychology, dlm. Burns, The Self Concept: Theory, Measurement, Development and Behaviour, 7.

17 Epstein, American Psychologist, 404-416. 
diri. ${ }^{18}$ Id adalah gerak hati yang tidak rasional, tidak bermoral, tidak berasa takut, dan penuh dengan keinginan untuk mencari keseronokan. Ego pula adalah set yang memproses apa yang dilihat dan difikirkan. Ia menentukan kandungan kesedaran dan menyesuaikan di antara realiti dan imaginasi berlawanan dengan $i d$, yang berfungsi melengahkan kepuasan bagi menuju dan mencapai prinsip kebenaran, manakala, super ego merupakan penghayatan segala nilai yang ada dalam masyarakat yang dipelajari untuk menghalang tingkah laku impulsif atau gerak hati yang terdapat pada id yang bersifat berlawanan dengan norma masyarakat. Selain itu, super ego berperanan dalam mempengaruhi ego agar bertingkah laku secara realistik dan bermoral bagi mencapai tahap cemerlang dan tingkah laku secara kekal. ${ }^{19}$ Freud cuba memperkenalkan pandangan bahawa kesedaran rasional mempunyai pengaruh dalam mengawal tingkah laku manusia. Namun dalam masa yang sama, beliau lebih cenderung berpendapat bahawa ketidaksedaran yang tidak rasional lebih menjadi penentu kepada tingkah laku manusia.

Walau bagaimanapun pendapat Freud ini disanggah oleh Adler. Beliau tidak bersetuju dengan pendapat Freud, yang lebih menekankan motivasi ketidaksedaran dalam menentukan tingkah laku. Beliau menekankan kesedaran sebagai pusat personaliti. Menurut Adler manusia sebagai makhluk yang sedar dan pada kebiasaannya mereka sedar terhadap sebab sesuatu tingkah laku itu dilakukan. Malah manusia juga mampu mengatur dan menentukan tindakan dan sedar terhadap implikasi yang akan diterima. Oleh kerana itu, bagi Adler 'cara hidup' yang menentukan tingkah laku individu. ${ }^{20}$

Berlainan pula dengan Allport yang menjelaskan konsep diri dari sudut yang berbeza. Beliau menggunakan istilah proprium untuk menjelaskan berkaitan diri. Proprium terdiri daripada lapan sifat iaitu (1) kesedaran terhadap badan, (2) kesinambungan dari masa ke semasa, (3) peningkatan ego, atau keperluan untuk harga diri, (4) lanjutan ego, atau pengenalan diri di luar sempadan badan,

18 Anna Freud, The Ego and the Mechanism of Defence, dlm. Burns, The Self Concept: Theory, Measurement, Development and Behaviour, 17-18.

19 Habibah \& Noran Fauziah, Psikologi Personaliti, 19-21.

20 Alfred Adler, The Practice and Theory of Individual Psychology, dlm. Burns, The Self Concept: Theory, Measurement, Development and Behaviour, 19. 
(5) proses rasional atau sintesis keperluan dalaman dengan realiti luar, (6) imej sendiri atau persepsi orang itu dan penilaian dirinya sebagai objek berpengetahuan, (7) diri sebagai Maha Mengetahui atau sebagai ejen eksekutif, (8) berusaha bersungguh-sungguh atau bermotivasi untuk meningkatkan diri bukannya mengurangkan ketegangan serta meningkatkan kesedaran dan mencari cabaran. ${ }^{21}$ Walau bagaimanapun, terdapat kesukaran untuk menjelaskan teori ini kerana seseorang itu tidak boleh mengenal pasti proprium sehingga anggapan orang lain menjadi dasar dalam mengenal pastikannya. Allport menganggap seseorang yang matang akan memperoleh keseluruhan konsep kendirinya yang sebenar dalam mencapai tahap kedewasaan. ${ }^{22}$

Mead menjelaskan bahawa diri individu berkembang hasil daripada hubungan-hubungan terhadap proses aktiviti sosial dan pengalaman bersama individu-individu lain di dalam proses-proses tersebut. Konsep diri merupakan objek yang muncul dalam interaksi sosial hasil daripada kebimbangan individu tentang bagaimana orang lain bertindak balas kepadanya. ${ }^{23}$ Tindak balas orang lain terhadap pembentukan konsep kendiri individu diumpamakan oleh Cooley sebagai konsep "diri melihat cermin" yang merujuk kepada individu melihat dirinya melalui pandangan orang lain terhadapnya. ${ }^{24}$

Bagi memahami secara berstruktur dan lebih mudah berkaitan konsep kendiri, Rogers telah membincangkannya secara terperinci. Menurut beliau, konsep kendiri terdiri daripada gabungan persepsi individu terhadap diri sendiri dan penilaian orang lain terhadap dirinya serta penilaiannya terhadap persepsi orang lain kepada dirinya (Rujuk Rajah 1$)^{25}$ dengan melihat bagaimana seseorang itu berfikir dan melihat dirinya berdasarkan kesedarannya tentang kekuatan dan kelemahannya serta persepsi orang lain. Misalnya,

${ }^{21}$ Gordon Willard Allport, Becoming New Haven, dlm. Burns, The Self Concept: Theory, Measurement, Development and Behaviour, 22-23.

22 Gordon Willard Allport, Pattern and Growth in Personality, dlm. Burns, The Self Concept: Theory, Measurement, Development and Behaviour, 23.

${ }^{23}$ George Mead, Mind, Self, and Society, dlm. Burns, The Self Concept: Theory, Measurement, Development and Behaviour, 15.

${ }^{24}$ Charles Horton Cooley, Human Nature and the Social Order (New York: Scribners, 1902), 152.

25 Carl Rogers, Client Centered Therapy, dlm. Burns, The Self Concept: Theory, Measurement, Development and Behaviour, 37-38. 
jika seseorang individu merasakan dirinya jahat dan orang lain menunjukkan reaksi tidak menyukai dirinya kemudian dia menilai reaksi tersebut sebagai pengukuhan kepada penilaian dirinya. Maka individu tersebut terdorong untuk bertingkah laku seiring dengan apa yang dipersepsikan terhadap dirinya iaitu bertingkah laku sebagai orang jahat. Begitu juga sebaliknya, jika seseorang individu mempersepsi dirinya sebagai orang baik kemudian diperkukuhkan dengan persepsi orang terhadap dirinya sebagai orang yang baik, maka individu tersebut terdorong untuk bertingkah laku sebagai orang yang baik.

Rajah 1: Pembentukan Konsep Kendiri Rogers

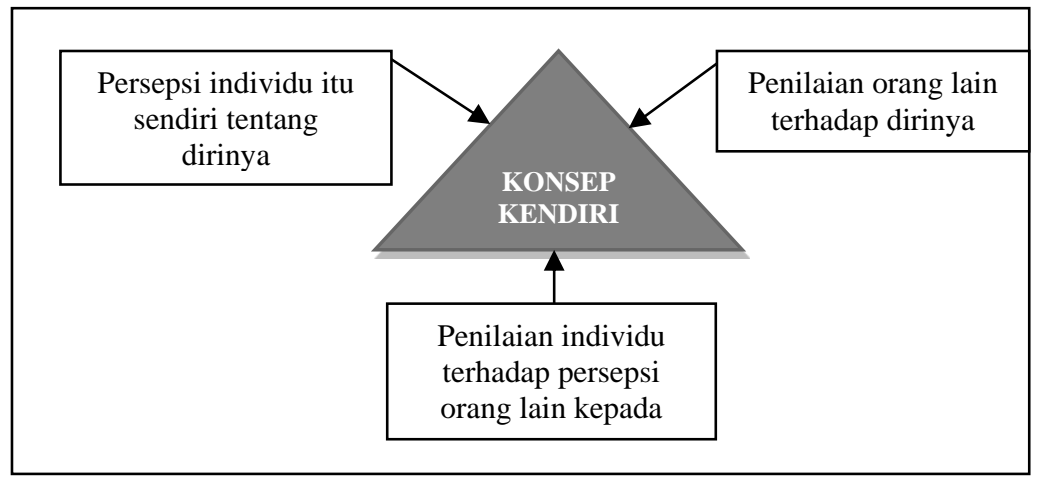

Bagi membina konsep kendiri yang positif, terdapat perbincangan berkaitan dengannya dalam proses terapi kaunseling. Pembinaan konsep kendiri diberi penekanan dalam teori pendekatan pemusatan klien yang diperkenalkan oleh Carl Rogers. Teori tersebut mengandaikan bahawa individu bertingkah laku dalam bentuk yang boleh meningkatkan konsep kendirinya dan masalah-masalah yang berlaku disebabkan wujudnya antara konsep kendiri dengan pengalaman-pengalaman yang lalu. Rogers berpegang kuat bahawa sifat tabii manusia boleh berkembang serta terbina secara positif melalui nilai kepercayaan dan hormatmenghormati yang boleh dirasai serta menolak bahawa manusia tidak boleh dipercayai, pasif dan menjadi mangsa sifat biologi atau persekitaran sehingga perlu diarah, didorong, dikawal dan diuruskan kehidupannya oleh orang lain. Prinsip ini memberi kekuatan kepada manusia untuk membangunkan konsep kendiri 
mereka tanpa dipengaruhi oleh orang lain. ${ }^{26}$ Rogers mendapati bahawa hasil utama sesi terapi beliau ialah subjek menjadi lebih positif dalam pandangannya terhadap diri dan sikap subjek juga lebih positif kepada orang lain. Terdapat kecenderungan ke arah hubungan yang konsisten di antara sikap terhadap diri dan sikap terhadap orang lain. Di luar konteks terapi pula, kajian mendapati individu yang memiliki konsep kendiri yang positif adalah kurang prejudis dan lebih bersedia untuk berinteraksi dengan orang yang berlainan etnik dari dirinya berbanding dengan individu kurang memiliki konsep kendiri positif. ${ }^{27}$

Azizi dan rakan-rakan pula telah menyenaraikan beberapa langkah yang boleh dilaksanakan bagi membina konsep kendiri yang positif. Antaranya ialah membina suatu kemahiran, belajar untuk menerima diri seadanya, memerhatikan orang yang mempunyai harga diri yang tinggi, membaca biografi atau menonton video orang yang dikagumi, orang yang berjaya atau terkemuka, menyenaraikan kelebihan yang ada pada diri, berhenti daripada berlengah-lengah, mencari seorang mentor dan menggunakan pertuturan kendiri positif. Selain daripada itu, Azizi dan rakan-rakan turut menyenaraikan agar berhati-hati daripada kesan pygmalion. Kesan pygmalion ialah kecenderungan yang membenarkan komunikasi orang lain mempengaruhi tingkah laku diri. $^{28}$

Menurut Burns, kebanyakan orang memberi pengaruh ke atas orang lain melalui komunikasi sama ada dengan memberi tanggapan positif ataupun negatif terhadap seseorang itu. Kuasa tanggapan mampu mempengaruhi tingkah laku dan prestasi orang lain. Namun, kadang-kadang kekuatan kuasa tanggapan ini tidak disedari dalam mempengaruhi diri seseorang individu. Tanggapan yang mengetuai cara seseorang itu berfikir tentang dirinya atau maklum balas yang mereka terima daripada orang lain menjadi ramalan dalam memuaskan hati sendiri melalui cara bercakap pada diri. Jika seseorang itu bercakap dengan diri secara positif maka

${ }^{26}$ Melati Sumari, Ida Hartina Ahmed Tharbe, Norfaezah Md Khalid \& Azmawaty Mohamad Nor, Teori Kaunseling dan Psikoterapi (Kuala Lumpur: Penerbit Universiti Malaya, 2014), 44.

27 R.B. Burns, Essential Psychology, ed. ke-2 (United Kingdom: Kluwer Academic Publishers, 1991), 175.

28 Azizi Yahaya et. al, Pembangunan Kendiri, 36-40. 
konsep kendiri mereka berkembang secara positif. Sebaliknya, jika mereka bercakap dengan diri secara negatif maka kecenderungan konsep kendiri berkembang secara negatif. ${ }^{29}$ Oleh itu, apa yang perlu setiap individu lakukan adalah berhati-hati dengan bagaimana mereka bercakap kepada diri sendiri dengan mengawal apa yang dikatakan kepada diri serta berhati-hati dalam menerima pendapat dan sikap orang di sekeliling mereka terutama yang membawa kepada unsur yang negatif.

Apa yang pasti, proses perkembangan konsep kendiri tidak akan berhenti pada sesuatu tahap. Menurut Burns, konsep kendiri terbina secara berterusan berdasarkan kemunculan potensi-potensi baru yang ditemui bermula dari lahir hingga tiba masa kematian. ${ }^{30}$ Apa yang diperlukan ialah manusia perlu mencari potensi-potensi yang boleh membangunkan kendiri mereka dengan melihat dan memberi tumpuan kepada aspek-aspek yang positif yang terdapat pada diri. Misalnya, jika seseorang itu kurang berjaya dalam keputusan akademik sebaiknya dia tidak perlu merasa lemah dan rendah diri tetapi cuba mencari dan melihat kelebihan lain seperti bakat-bakat lain yang terdapat pada diri.

\section{Pembinaan Konsep Kendiri dari Perspektif Islam}

Dalam membicarakan konsep kendiri dari perspektif Islam, ahli falsafah Islam tidak membincangkan dan menggunakan istilah tersebut secara khusus. Namun, secara konsepnya terdapat perbincangan berkaitannya dalam Islam. Sebelum perbincangan dan kupasan berkaitan konsep kendiri dilakukan secara mendalam, sebaiknya perlu memahami terlebih dahulu perspektif Islam terhadap konsep diri manusia. Ini kerana ia merupakan asas dan dasar dalam memahami perspektif Islam terhadap konsep kendiri.

Ahli-ahli falsafah dan psikologi Islam berpegang kepada pendapat yang hampir sama berkaitan diri manusia. Ini kerana mereka menjadikan al-Quran sebagai sumber rujukan utama dalam membincangkan dan mengupas berkaitan diri. Ayat-ayat Al-Quran banyak menyentuh elemen-elemen yang terdapat pada diri manusia terutama yang bersifat dalaman atau kerohanian. AlGhazāli antara tokoh falsafah Islam yang memberi kupasan yang

29 Burns, Essential Psychology, 170.

30 Burns, The Self Concept: Theory, Measurement, Development and Behaviour, 149. 
mendalam berkaitan diri dan menjadi rujukan oleh kebanyakan ahli-ahli psikologi Islam yang lain. Menurut beliau, setiap kejadian diri manusia merangkumi 4 unsur utama iaitu (1) al-rūh (roh), (2) al-qalb (hati), (3) al-nafs (nafsu), dan (4) al- 'aql (akal). ${ }^{31}$ Setiap satunya mempunyai fungsi yang tersendiri dalam membentuk satu entiti diri manusia.

Al-rūh (roh)Tidak banyak yang boleh diperjelaskan tentang roh kerana al-Quran dan Rasulullah SAW tidak banyak membahaskannya. Berdasarkan maklumat yang sedikit itu ahli falsafah Islam seperti al-Ghazāli mendefinisikan roh sebagai suatu jisim halus yang tersebar ke seluruh bahagian badan dengan perantaraan urat-urat dan otot. Roh berhubung dengan pancaindera dengan memberi kesan kepada perasaan dan emosi di dalam diri individu. $^{32}$

Sebagaimana jasad mempunyai tuntutan seperti makan dan minum begitu juga dengan roh. Roh pula mempunyai tuntutan daripada alam ketinggian dan kekudusan yang meliputi akidah, akhlak dan pengabdian. ${ }^{33}$ Al-Kindī menyatakan roh merupakan elemen yang memiliki kehormatan dan kesempurnaan, berkedudukan luhur dan zatnya daripada zat Maha Pencipta. ${ }^{34}$ Oleh itu, tuntutan roh adalah kepada akidah dan penghambaan yang murni kepada Maha Pencipta iaitu Allah SWT dengan mengingati-Nya melalui ibadah solat, zakat, puasa, berakhlak mulia, menuntut ilmu dan lain-lain lagi.

Al-qalb (hati) dari segi fizikal, merupakan seketul daging yang terletak di sebelah kiri dada manusia. ${ }^{35}$ Dari sudut sains, ia merupakan satu organ yang amat penting yang mengumpulkan dan menyebarkan darah ke seluruh badan dan merupakan sumber

31 Soleh Ahmad al-Shamī, Al-Muhazzibu min Ihȳ̄' 'Ulūm al-Dīn, ed. ke-3 (Dimasyq: Dār al-Qalam, 2010), 2:10.

32 Fariza Md Sham, Salasiah Hanin Hamjah \& Mohd. Jurairi Sharifudin, Personaliti dari Perspektif al-Ghazali (Bangi: Fakulti Pengajian Islam, UKM, 2008), 24-25.

33 Haron Din, Manusia dan Islam, ed. ke-6 (Kuala Lumpur: Dewan Bahasa Dan Pustaka, 2010), 2:7.

34 Al-Kindī, al-Qawl fī al-Islām, dlm, Dr. Muhammad 'Uthmān Najātī, AlDirāsāt al-Nafsānīyah 'Indi al- 'Ulamā' al-Muslimīn (Beirut: Dār Al-Shurūk, 1993), 25-26.

35 Fariza et. al, Personaliti dari Perspektif al-Ghazali, 23. 
nyawa atau kehidupan manusia. ${ }^{36}$ Dari sudut rohani, al-Ghazāli menyifatkan hati sebagai raja kepada seluruh anggota manusia. Semua anggota bernaluri untuk tunduk kepada hati. ${ }^{37}$ Ini bermakna hati mempunyai peranan penting dalam menentukan tingkah laku manusia. Hati yang baik akan membentuk manusia yang bertingkah laku baik. Sebaliknya, jika hati itu buruk maka manusia cenderung kepada bertingkah laku kurang baik seperti melakukan kejahatan dan kemungkaran. Ciri-ciri dan keutamaan hati jelas disebut dalam hadis berikut.

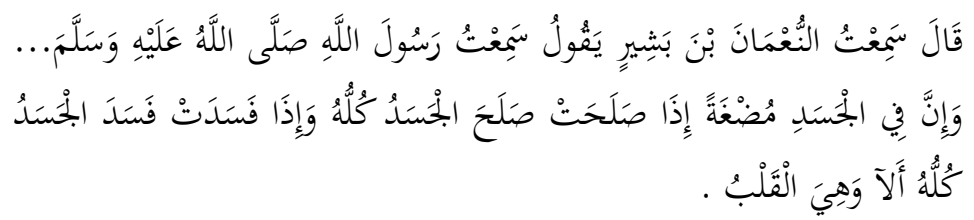

Terjemahan: Daripada al-Nu'man ibn Basyir r.a. berkata: Aku telah mendengar Rasulullah SAW bersabda: ... "Ketahuilah bahawa dalam setiap jasad itu ada seketul daging yang apabila ia baik maka baiklah seluruh jasad dan apabila ia rosak, maka rosaklah seluruh jasad. Ketahuilah ia adalah hati.", 38

Menurut al-Ghazāli lagi, hati manusia mempunyai hubungan yang rapat dengan alam ghaib. Melaluinya manusia dapat menerima maklumat-maklumat berhubung dengan alam ghaib dan diberi ilham kepada manusia tentang hakikat diri dan Allah SWT. ${ }^{39}$ Hati yang sentiasa mengingati Allah SWT akan memancarkan cahaya. Cahaya inilah yang akan tersebar ke seluruh anggota tubuh dan dizahirkan melalui perbuatan dan raut wajah yang tenang. Namun, apabila hati lalai dengan perkara-perkara yang mungkar maka ia akan terhalang daripada mengenali Allah SWT dan jika berterusan, hati akan semakin gelap dan susah untuk

${ }^{36}$ Mahmood Nazar Mohamed, Pengantar Psikologi: Satu Pengenalan Kepada Jiwa dan Tingkah Laku Manusia (Kuala Lumpur: Dewan Bahasa \& Pustaka, 2001), 31.

37 Al-Ghazali, dlm, Nor Anisah Abdul Malek, Konsep Manusia Menurut Pandangan Islam (Kuala Lumpur: Arena Ilmu Sdn. Bhd., 1992), 32.

38 Abī 'Abd Allāh Muhammad bin Ismā'īl al-Bukhārī, Șahīh Bukhārī, ed. Muḥamad 'Abd al-Qādir Ahmad 'Atō (Kāherah: Dār al-Taqwa Lilturāth, 2001), 1:19-20, Hadis no. 50, Bab no. 36, Kitab no. 2.

39 Al-Ghazālī, Ihyā' 'Ulūm al-Dīn (Kaherah: Dār al-Taqwa Lilturath, 2000), 2:531. 
menerima kebenaran. Ini akan membawa manusia ke lembah kehancuran.

Al-nafs (nafsu) pula adalah unsur dalaman manusia yang mampu membawa manusia ke arah keburukan dan kejahatan. Di situlah pusat bagi kekuatan marah dan syahwat manusia. ${ }^{40}$ Sehinggakan ia dianggap sebagai musuh paling besar pada diri setiap manusia. ${ }^{41}$ Hal ini kerana sifat nafsu itu yang sangat mendorong manusia untuk melakukan kejahatan. ${ }^{42}$

Al-Ghazāli membahagikan nafsu kepada tiga peringkat ${ }^{43}$ iaitu (1) nafsu mutmainnah iaitu nafsu yang bersifat tenang dan baik serta mempunyai nilai kemuliaan, ${ }^{44}$ (2) nafsu lawwāmah pula ialah nafsu penyesalan ${ }^{45}$ yang tidak mencapai ketenangan sepenuhnya. Berada di tengah-tengah naluri manusia dan cenderung bergerak ke arah kebaikan atau ke arah keburukan. ${ }^{46}$ Peringkat nafsu terakhir ialah (3) nafsu 'ammarah yang disifatkan sebagai satu bentuk dorongan yang mendorong seseorang individu melakukan kejahatan ${ }^{47}$ atau mengambil tindakan melanggar nilai-nilai kemuliaan dalam kehidupan. ${ }^{48}$

Bagi membina diri yang positif, setiap individu perlu berusaha untuk membina dalaman diri sehingga mencapai peringkat nafsu yang terbaik (nafsu mutmainnah) agar mampu mengawal nafsu 'ammarah daripada menguasai diri. Namun begitu, untuk mengawal nafsu bukan sesuatu yang mudah kerana nafsu dikelilingi dengan perkara-perkara yang menyeronokkan dan melazatkan. Sebagaimana sabda Nabi Muhammad SAW dalam sebuah hadis.

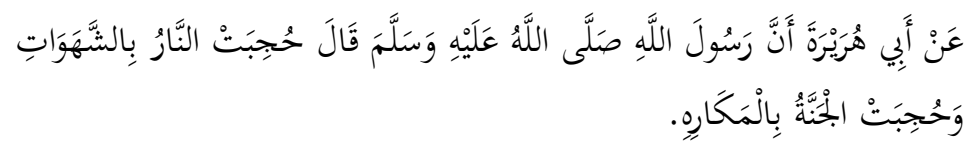

40 Yatimah Sarmani \& Mohd. Tajudin Ninggal, Teori Kaunseling al-Ghazali. (Selangor: PTS Islamika, 2008), 37.

41 Al-Ghazali, Mutiara Ihya' Ulumuddin, terj. Irwan Kurniawan (Bandung: PT Mizan Pustaka, 2008), 205.

42 Al-Quran, Surah Yusuf 12: 53

43 Al-Ghazālī, Ihyā' 'Ulūm al-Dīn, 532.

44 Al-Quran, Surah al-Fajr 89: 27-28.

45 Al-Quran, Surah al-Qiyāmah 75: 2.

46 Fariza et. al, Personaliti dari Perspektif al-Ghazali, 26.

47 Al-Quran, Surah Yusuf 12: 53.

48 Fariza et. al, Personaliti dari Perspektif al-Ghazali, 26-27. 
Terjemahan: "Neraka di kelilingi dengan syahwat (hal-hal yang menyenangkan nafsu), sedang syurga di kelilingi hal-hal yang tidak disenanginya." 49

$A l$ - $a q l$ (akal) elemen yang menjadi pelengkap kepada diri. Al-Ghazāli memberi pengertian akal kepada empat maksud. ${ }^{50}$ Pertama, pada asasnya, akal adalah umpama cahaya yang masuk ke dalam hati yang disediakan untuk mengetahui pelbagai perkara. Akal diciptakan oleh Allah SWT sebagai suatu naluri untuk mencapai ilmu-ilmu nazari ${ }^{51}$. Kedua, akal adalah ilmu pengetahuan yang wujud dalam diri manusia sejak kanak-kanak lagi dalam membantu membezakan tentang perkara-perkara yang mungkin dan perkara-perkara yang mustahil. Seperti mengetahui bahawa seseorang tidak berada di dua tempat pada satu masa yang sama. Ketiga, akal adalah ilmu pengetahuan yang diperoleh daripada pengalaman. Orang yang melalui banyak pengalaman dan memahami serta menghayati setiap pengajaran yang diperoleh biasanya dikatakan sebagai orang yang berakal atau matang. Keempat, akal juga sebagai kekuatan daripada naluri yang akhirnya mampu mengetahui akibat daripada segala perkara serta mampu mengawal hawa nafsu untuk menuju kepada kebaikan dan kesenangan.

Jadi tidak hairanlah, dengan keajaiban akal yang diciptakan oleh Allah SWT, manusia mampu menerima wahyu dan memahaminya dengan baik. ${ }^{52}$ Ciri-ciri akal yang sangat istimewa ini telah membezakan manusia dengan haiwan dan makhlukmakhluk yang lain. Walau bagaimanapun, menurut Harun Din, kelebihan akal manusia adalah terbatas. Manusia tidak dapat menyelesaikan masalah dengan hanya menggunakan akal mereka sahaja. Hal ini kerana akal mereka mempunyai kelemahan yang sangat ketara. Antara kelemahan akal manusia adalah berlainan dan berbeza dalam menentukan nilai-nilai hidup atau menentukan baik atau jahat. Di tambah pula akal manusia mudah dipengaruhi oleh hawa nafsu, perkauman, berpuak-puak dan semangat

49 Al-Bukhārī, Sahīh Bukhārī, hadis no. 6006, Bab no. 28, Kitab no. 61.

50 Musa Fathullah Harun, Pengantar Tasawwuf Islam (Sungai Buloh: Dr.Musa Bin Fathullah Harun,1996), 211-213

51 Ilmu nazari: llmu teoritikal

52 Sayyid Quthb, Tafsīr fì Zhīlalīl Qur'ān di Bawah Naungan al-Quran terj, As'sd Yasin (Jakarta: Gema Insan Press, 2003), 7:144. 
mementingkan diri. Selain daripada itu, akal manusia tidak mampu membuat ramalan yang tepat dalam menentukan peristiwa yang akan berlaku kelak. Banyak peristiwa berlaku di luar jangkaan manusia. Akal manusia juga dipengaruhi oleh tabiat manusia yang tidak menghormati undang-undang sendiri sebab undang-undang manusia itu tidak menghubungkan dengan pembalasan di akhirat hanya ditumpukan kepada dunia semata-mata. ${ }^{53}$

Walaupun keempat-empat unsur tersebut mempunyai fungsi yang tersendiri, namun, setiap satunya berkait di antara satu sama lain dalam membentuk diri individu. Roh dan akal merupakan unsur yang bersifat ketuhanan cenderung kepada kemuliaan dan kebaikan manakala untuk mengelak daripada kehinaan dan keburukan sering diancam oleh sifat-sifat nafsu. Nafsu dikatakan terbina dengan dua elemen iaitu elemen kebinatangan dan syaitan. Elemen-elemen ini mendorong kepada pemuasan nafsu sematamata sehingga melawan kehendak roh dan akal. Hati pula yang merupakan pusat kepada permulaan bagi penggerak tingkah laku bertanggungjawab untuk mengawal kegiatan-kegiatan roh, nafsu dan akal yang berupaya bergerak ke arah kebaikan atau kejahatan. Menurut Harun Din, di dalam tubuh setiap manusia mengandungi dua tenaga. ${ }^{54}$ Pertama tenaga yang berada di bawah pengendalian akal yang dapat membezakan antara perkara baik atau buruk. Tenaga ini menggerakkan dan mendorong manusia untuk melakukan kebajikan, berkasih sayang, tolong-menolong dan segala perbuatan baik. Manakala tenaga yang kedua, tenaga yang mengarahkan manusia untuk melakukan kerosakan seperti tamak, hasad dengki, pergaduhan, memfitnah dan banyak lagi. Tenaga ini berada di bawah kawalan nafsu yang sering untuk memuaskan kehendak naluri yang liar. ${ }^{55}$ Hati menerima atau meminta bantuan daripada gagasan akal dalam menjaga kemuliaan roh dari ancaman nafsu jahat. Hati kadang-kadang dapat menguasai nafsu dan ada kalanya gagal. Hati akan menang jika dapat menggunakan kekuatan akal. Hati yang gagal mengawal nafsu dalam mencapai ketenangan (nafsu mutmainnah) adalah hati yang gagal dalam tugasnya menjaga roh. Apabila tuntutan roh tidak dipenuhi, maka,

\footnotetext{
53 Harun Din, Islam: Ada Apa Dengan Islam? (Batu Caves: PTS Millennia Sdn. Bhd., 2007), 51-52.

54 Harun Din, Islam: Ada Apa Dengan Islam?, 49.

55 Al-Quran, Surah Al-Syams 91:7-10
} 
individu tidak mudah untuk mengawal nafsu dan nafsu mudah dipengaruhi oleh naluri jahat (nafsu amarah) yang cenderung kepada perkara-perkara di luar batasan norma dan agama. ${ }^{56}$

Oleh yang demikian, bagi membina diri yang baik perlu kepada keseimbangan keempat-empat unsur ini. Keseimbangan yang terhasil daripada kekuatan hubungan dengan Allah SWT yang terzahir dengan perbuatan dan tindakan berpaksikan syariatNya bagi mendapat keredaan-Nya. Menurut Ibnu Qayyim, roh atau jiwa yang berada di dalam keadaan yang baik dan sihat menjadikan seseorang itu dapat melihat kebenaran dan keburukan sesuatu itu dengan jelas. ${ }^{57}$ Ini mendorong individu tersebut melakukan perbuatan yang baik dan terpuji serta menghalang daripada melakukan perkara yang buruk dan menyimpang. ${ }^{58}$ Namun sebaliknya, jika unsur-unsur ini tidak dapat diseimbangkan dengan jalan yang betul, akan merosakkan konsep dan kehendaknya kepada kebenaran sehingga tidak dapat melihat kebenaran sebagai satu kebenaran. ${ }^{59}$

Berdasarkan huraian di atas jelas menunjukkan konsep diri dari perspektif Islam mempunyai kaitan yang kuat dengan alam ketuhanan. Unsur-unsur kejiwaan perlu diseimbangkan agar diri dapat mencapai tuntutan sebenar kerohanian. Tuntutan yang mendekatkan diri dengan Penciptanya sekali gus membentuk jiwa yang suci, bersih, tawaduk dan penuh rasa kehambaan. Adanya panduan daripada al-Quran dan hadis Nabi Muhammad SAW dapat membantu manusia untuk mencapai tuntutan tersebut.

Konsep diri inilah yang dipantulkan dalam konsep kendiri setiap individu mukmin. Oleh itu, tanpa menolak tiga elemen yang dikemukakan oleh Rogers, terdapat elemen lain di dalam Islam yang tidak dapat tidak turut mempengaruhi konsep kendiri individu iaitu penilaian terhadap pandangan Pencipta terhadap diri. Sudah tentu elemen ini bukan sahaja mempengaruhi konsep kendiri individu Muslim malah individu lain terutama mereka yang mempunyai keimanan terhadap konsep tuhan. Ini kerana

${ }^{56}$ Fariza et. al, Personaliti dari Perspektif al-Ghazali, 30-32.

57 Ibn Qayyīm al-Jawziyyah, Tuhfah al-Mawdūd bi Aḥkām al-Mawlūd, tahq. 'Abdul al-Qādir al-Arnaud (Damaskus: Maktabah Dār al-Bayān, 1971), 300302.

58 Mohammad Salleh, Terapi Solat Tahajud (Kuala Lumpur: PTS Millennia Sdn.Bhd., 2008), 72.

59 Ibn Qayyīm al-Jawziyyah, Tuhfah al-Mawdūd bi Ahkām al-Mawlūd, 300-302. 
fitrah setiap manusia berkait dengan alam ketuhanan walaupun ada yang menafikan kewujudan tuhan di alam ini. ${ }^{60}$ Secara ringkasnya, Rajah 2 di bawah menunjukkan elemen-elemen yang membentuk konsep kendiri menurut perspektif Islam.

\section{Rajah 2: Pembentukan Konsep Kendiri Menurut Perspektif Islam}

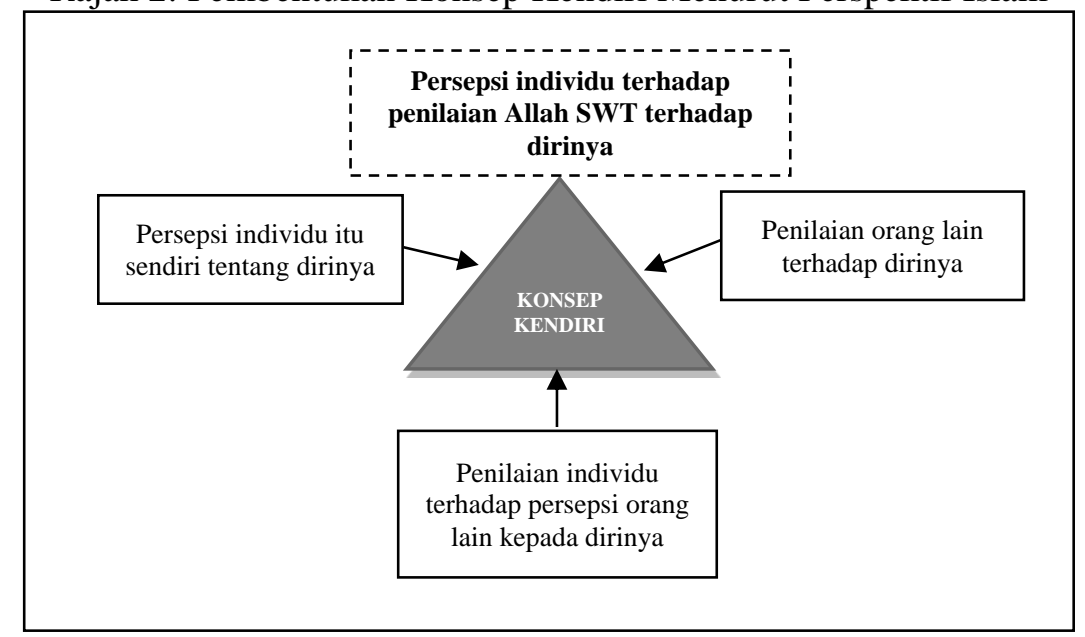

Islam telah menyediakan garis panduan kepada manusia sebagai kayu ukur untuk pembinaan konsep kendiri iaitu dengan mengambil kira pandangan Allah SWT terhadap diri melalui tuntutan dan larangan yang termaktub di dalam al-Quran dan hadis. Apabila seseorang manusia itu menilai dirinya berdasarkan pandangan Allah SWT, maka, ia akan berusaha melakukan segala tuntutan Allah SWT demi mencapai keredaan-Nya. Jiwa tidak tenang dan selesa apabila tuntutan ini tidak ditunaikan. Misalnya, golongan Muslim yang melakukan solat dapat merasakan ketenangan berbanding mereka yang tidak melakukan solat. Ini kerana menunaikan tuntutan utama Allah SWT menjadikan mereka merasai penerimaan baik Allah SWT terhadap diri mereka. Rentetan daripada itu, mendorong individu untuk membina diri yang lebih positif sekali gus, membentuk peribadi berkualiti. Sebaliknya, jika seseorang melakukan kemungkaran akan menimbulkan keresahan dan kebimbangan terhadap bukan sahaja

${ }^{60}$ Engku Ahmad Zaki Engku Alwi, Membangun Modal Insan Melalui Pemantapan Akidah ( Putrajaya: Jabatan Kemajuan Islam, 2007), 13-19. 
penerimaan manusia malah penerimaan Allah SWT. Kebimbangan dan keresahan ini jika tidak dihilangkan dengan memohon maaf dan taubat akan memberi kesan negatif seperti melahirkan rasa putus asa dan mendorong dalam melakukan kemungkaran.

Pembinaan konsep kendiri yang positif dalam Islam adalah pembinaan konsep kendiri yang seimbang. Apa yang dimaksudkan dengan konsep kendiri seimbang ialah penilaian atau persepsi yang dilakukan individu terhadap dirinya tidak terlalu rendah sehingga melahirkan sifat putus asa pada diri dan juga tidak terlalu tinggi sehingga melahirkan sifat ujub ${ }^{61}$. Ini dinyatakan oleh Ibnu Mas'ud bahawa kebinasaan itu terletak dalam dua perkara iaitu putus asa dan ujub. Ini kerana menurut beliau kebahagiaan tidak boleh diperoleh dengan sifat malas. Orang berputus asa itu biasanya tidak lagi suka berusaha dan tidak pula mencari apa-apa yang dicita-citakannya. Manakala, sifat ujub pula menyebabkan seseorang itu menganggap tiada gunanya untuk berusaha kerana seolah-olah individu berkeyakinan dirinya sudah mencapai kebahagiaan, keselamatan dan kesejahteraan. ${ }^{62}$

Sifat putus asa tidak disukai di dalam Islam kerana sifat ini boleh mendorong manusia untuk melakukan perbuatan mungkar. ${ }^{63}$ Misalnya, seseorang yang merasa rendah diri disebabkan sering kali gagal dalam mendapatkan pekerjaan, jika tidak dapat diatasi dengan baik dan berlarutan akan melahirkan perasaan putus asa. Perasaan putus asa ini boleh menyebabkan individu tersebut tidak mahu bekerja ataupun mengambil jalan mudah dengan melakukan pekerjaan yang menyalahi undang-undang sebagai sumber pendapatan mereka.

Tegahan terhadap sifat ujub pula jelas terkandung di dalam beberapa ayat di dalam al-Quran. ${ }^{64} \mathrm{Al}-$ Ghazāli telah

${ }^{61}$ Sifat ujub bermaksud berasa bangga pada diri sendiri, berasa hairan terhadap diri sendiri dengan sebab adanya sesuatu dan lain-lain perkara. (Al-Syeikh Muhammad Jamaluddin al-Qasimi Ad-Dimasqi, Mutiara Ihya' Ulumuddin Hak Milik Muslim: Imam al-Ghazali, terj. Norzuzilawati et al. (Selangor: Illusion Network, 2009), 953).

62 Ibnu Mas'ud, dlm, Ad-Dimasqi, Mutiara Ihya' Ulumuddin Hak Milik Muslim: Imam al-Ghazali, 955.

${ }^{63}$ Surah Hud 11: 9-11; Surah Yusuf 12: 87; Surah Al-Isra' 17: 83; Surah AlRum 30: 36; Surah Fussilat 41:49.

${ }^{64}$ Surah Al-Tawbah 9:25; Surah Al-Kahf 18:104; Surah Al-Najm 53: 32; Surah al-Hashr 59: 2. 
menyenaraikan keburukan sifat ujub ini iaitu sifat ujub boleh menimbulkan rasa sombong dan takabbur sehingga seseorang itu kurang sedar dengan kelemahan yang ada pada dirinya. Individu tersebut menilai dirinya sebagai orang yang bijak dan pandai berbanding orang lain dan mengagumi dirinya lalu tidak mahu menerima pendapat orang lain. Selain itu, sifat ujub membawa seseorang bersikap mengutamakan diri bagi memenuhi kemahuannya. Apa yang lebih membimbangkan, sifat ujub boleh membawa seseorang itu melampau batas kerana individu yang merasakan dirinya terlalu berkuasa dan kuat, cenderung untuk menindas orang lain. ${ }^{65}$ Sifat ujub pada diri ini jelas banyak membawa seseorang kepada sikap-sikap yang negatif.

Sifat putus asa dan ujub ini terjadi disebabkan apabila seseorang itu hanya mengutamakan pandangan diri sendiri dan pandangan orang lain terhadap dirinya semata-mata. Mereka tidak meletakkan pandangan Allah SWT dalam menilai diri. Misalnya, sifat putus asa berlaku bila seseorang itu putus harapan apabila tidak mendapat sokongan atau hilang tempat pergantungan daripada orang lain. Namun, bagi individu yang meletakkan pergantungan pada Allah SWT, maka pergantungan ini akan kekal selagi mereka sendiri tidak berpaling pada-Nya. Bagi mereka, walaupun dipandang sinis daripada orang lain dan apa sahaja kelemahan pada dirinya, selagi tidak menyalahi atau bertentangan dengan pandangan Allah SWT mereka dapat menerimanya dengan baik kerana Allah SWT. Sifat ujub pula tidak berlaku jika manusia mengetahui dan merasakan segala pujian sama ada kekuasaan, kebaikan, kebijaksanaan, dan kehebatan yang ada pada diri adalah datangnya daripada Allah SWT. Oleh itu, al-Ghazāli berpendapat bahawa perkara yang seharusnya dilakukan bukannya ujub tetapi berterima kasih serta bersyukur kepada Allah SWT yang menganugerahkan kenikmatan tersebut. ${ }^{66}$

Oleh itu, bagi membina konsep kendiri positif atau konsep kendiri yang seimbang seseorang perlu mengelakkan sifat putus asa dan ujub yang merupakan sifat-sifat mazmumah (sifat tercela). Bagi mengelakkan sifat mazmumah ini, al-Ghazāli menyarankan

65 Al-Ghazali, Ihya' Ulumuddin, dlm, Ad-Dimasqi, Mutiara Ihya' Ulumuddin Hak Milik Muslim: Imam al-Ghazali, 956-959.

66 Al-Ghazāli, dlm, Ad-Dimasqi, Mutiara Ihya' Ulumuddin Hak Milik Muslim: Imam al-Ghazali, 960. 
agar melakukan amal ibadat kepada Allah SWT sebagaimana yang dituntut oleh ajaran Islam seperti solat, zakat dan sedekah, puasa, menunaikan haji, membaca al-Quran, berzikir mengingati Allah SWT, mencari rezeki yang halal, pergaulan baik dengan sesama manusia, amar makruf nahi mungkar serta mengikut sunah Rasulullah SAW. ${ }^{67}$ Amal ibadat bukan sahaja dapat membina hubungan langsung dengan Allah SWT malah dapat membina konsep kendiri positif yang seimbang.

\section{Perbincangan}

Setelah memahami konsep kendiri melalui dua perspektif tersebut, terdapat beberapa perkara penting yang dapat digariskan dalam penulisan ini. Antaranya ialah:

1) Perbezaan pembinaan konsep kendiri oleh Barat dan Islam.

Terdapat perbezaan dari sudut perspektif Islam terhadap pembinaan konsep kendiri berbanding perspektif Barat. Perbezaan ini berlaku disebabkan tunjang terhadap matlamat kehidupan manusia itu sendiri berbeza di antara Barat dan Islam. Barat hanya memberi tumpuan terhadap pengaruh daripada tindak balas sekeliling yang berbentuk fizikal sahaja sedangkan Islam mengambil kira hubungan dimensi ketuhanan dalam mempengaruhi konsep kendiri seseorang individu. Walaupun mereka tidak menafikan perkara-perkara yang berkait dengan tuhan dan alam ghaib, namun, bagi mereka semua itu berkait dengan konsep pemikiran manusia sahaja. ${ }^{68}$

Selain daripada itu, Barat dan Islam bersetuju bahawa tingkah laku manusia adalah hasil daripada dalaman diri individu. Namun, elemen dalaman daripada dua perspektif ini adalah berbeza. Barat memberi tumpuan kepada aspek-aspek yang berkait dengan kesihatan mental seperti emosi, tekanan, kemurungan dan lainlain. Manakala, Islam memandang dalaman tersebut dari aspek keseimbangan fungsi hati, nafsu dan akal bagi mencapai kesejahteraan roh. Kesejahteraan roh berkait dengan kekuatan

67 Al-Ghazāli, Kitāb al-Arbaīn fì Usūl al-Dīn, terj. Mohd. Suhail, 40 Prinsip Agama Penyucian Rohani Untuk Meraih Akhlak Terpuji (Batu Caves, Selangor, 2012), 32-112.

68 Mostafa Kamal Mokhtar, "Konsep Pembangunan Rohani Manusia: Kajian Perbandingan di antara Sufisme dan Psikologi," Jurnal Psikologi Malaysia 15(2001):1-20. 
hubungan dengan alam ketuhanan. Kekuatan hubungan roh dengan alam ketuhanan hanya dapat diperoleh melalui gabungan kekuatan hati yang bersih dan penilaian akal terhadap ilmu dalam mengawal kelemahan nafsu berdasarkan panduan al-Quran dan hadis. Sifat mahmudah yang terbentuk hasil daripada hubungan tersebut dapat membina konsep kendiri positif yang seimbang bagi memandu tingkah laku manusia mengikut nilai-nilai norma yang baik.

2) Tiada piawaian sebenar dalam penilaian manusia.

Perspektif Barat mengemukakan tiga elemen dalam membina konsep kendiri individu. Ketiga-tiga elemen tersebut berasaskan penilaian dan persepsi daripada manusia sahaja iaitu sama ada daripada orang lain ataupun daripada diri individu itu sendiri. Namun begitu, pandangan manusia yang subjektif menyebabkan penilaian manusia itu tiada batasan dan piawaian dalam menentukan baik buruk dalam membantu pembinaan konsep kendiri yang benar-benar positif. Sebagai contoh, apabila seseorang individu merasa dirinya kuat (konsep kendiri positif), menyebabkan individu tersebut bersemangat. Tetapi apabila merasa diri itu lebih kuat daripada orang lain boleh menyebabkan timbulnya perasaan bangga diri dan sombong sehingga cenderung untuk melakukan perbuatan yang tidak baik seperti menindas orang lain. Begitu juga, apabila seseorang individu merasa dirinya cantik dan bergaya (konsep kendiri positif), memberi keyakinan diri kepada individu tersebut untuk berhadapan dengan orang. Tetapi apabila merasa diri terlalu cantik boleh menyebabkan individu tersebut cenderung untuk memperkecilkan orang lain atau melakukan khianat terhadap orang lain yang memberi saingan terhadapnya.

Berlainan dengan elemen tambahan yang dikemukakan Islam dalam pembentukan konsep kendiri individu iaitu persepsi manusia terhadap pandangan Pencipta iaitu Allah SWT yang mempunyai piawaian tersendiri. Piawaian dan had baik buruk dalam pembinaan konsep kendiri seseorang individu. Piawaian dan batasan terkandung dalam sumber panduan Islam yang diberikan Allah SWT melalui sumber al-Quran dan hadis Nabi Muhammad SAW. Melalui sumber tersebut terdapat kaedah dalam membentuk individu berperibadi mulia sama ada dari dalaman dan 
luaran. Sebagai contoh, apabila individu merasakan dirinya memiliki kekuatan dan kecantikan, dalam masa yang sama, melalui panduan dan ajaran Islam individu tersebut sedar semua itu adalah anugerah Allah SWT dan hanya Dia yang Maha Besar dan Maha Indah. Ini dapat mengelakkan mereka memiliki sifat ujub atau bangga diri dan membentuk sifat rendah hati terhadap Allah SWT yang memandu mereka untuk tidak melakukan perbuatan yang ditegah oleh Allah SWT seperti sombong, bongkak dan khianat.

Bukan itu sahaja, melalui elemen tersebut juga individu dapat mengawal konsep kendiri negatif daripada mempengaruhi diri yang jika tidak dikawal boleh membentuk sikap putus asa. Sikap putus asa mampu memberi kesan yang negatif kepada manusia seperti kemurungan, kecewa, merasa lemah dan marah. Kesan negatif ini cenderung membawa manusia bertindak di luar norma seperti bersendirian, bertindak agresif, membunuh diri dan lainlain lagi. Melalui pergantungan terhadap pandangan Allah SWT seseorang individu tidak mudah merasa diri itu lemah dan hina apabila dia tahu apa yang dilakukan adalah benar dan tidak salah pada pandangan-Nya. Malah, Allah SWT menjadi tempat bergantung dalam menempuh segala ujian dan cabaran.

\section{3) Mengutamakan pandangan Allah SWT membantu mengatasi kesan pygmalion.}

Banyak kebaikan apabila diri tidak dipengaruhi dengan persepsi orang lain yang juga dikenali sebagai kesan pygmalion. Sebagaimana teori yang diperjelaskan oleh Barat bahawa untuk membentuk konsep kendiri yang positif individu perlu berusaha mengelak daripada kesan pygmalion. Namun begitu, teori Barat tidak menjelaskan secara khusus bagaimana langkah untuk mengelakkan kesan tersebut. Walaupun Islam tidak menafikan kesan tersebut dalam mempengaruhi konsep kendiri individu, namun, Islam mengemukakan pendekatan untuk mengelak atau mengurangkan kesan pygmalion tersebut iaitu dengan menggalakkan individu lebih mengutamakan pandangan Allah SWT dalam setiap keputusan dan tindakan. Mengutamakan pandangan Allah SWT ialah melakukan apa sahaja yang disyariatkan-Nya dengan melaksanakan apa yang diperintahkan 
dan menjauhi apa yang dilarang, ikhlas semata-mata hanya kerana Allah.

Misalnya, istiqamah pemakaian hijab oleh pelajar-pelajar wanita Islam yang belajar di luar negara terutamanya di negara Barat. Berdasarkan keikhlasan terhadap Allah SWT dan mengetahui hikmah pemakaian hijab iaitu dalam menjaga kehormatan dan melindungi diri, maka individu terbabit tetap memakainya, meskipun dikelilingi oleh masyarakat yang sangat kurang memakai hijab serta tiada ibu bapa atau penjaga yang memantau sebagaimana ketika berada di tanah air.

Begitu juga dengan golongan yang susah dan miskin. Walaupun ada di kalangan mereka dipandang hina dan dipulaukan oleh segelintir masyarakat, namun bagi mereka yang mengutamakan pandangan Allah SWT akan merasa ketenangan dan kebahagiaan di dalam hati selagi mereka tidak melakukan perkara yang dilarang oleh Allah SWT dan terus berusaha, berdoa dan bertawakal kepadanya. Ini kerana setiap perbuatan yang dilakukan kerana Allah SWT berasaskan nilai ketakwaan dapat memberi kebahagiaan dalam diri manusia. Sebagaimana firman Allah SWT:

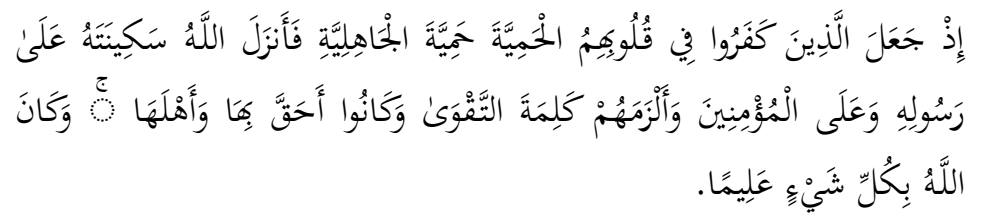

Maksudnya: "Ketika orang kafir menanamkan rasa sombong dalam hati mereka iaitu rasa sombong secara jahiliah, maka Allah menurunkan ketenangan kepada Rasul-Nya dan kepada orang mukmin dan (Allah) mewajibkan kepada mereka tetap taat menjalankan kalimah takwa dan mereka lebih berhak dengan itu dan patut memilikinya. Dan Allah Maha Mengetahui segala sesuatu."

Al-Fath 48:26

\section{Penutup}

Berdasarkan huraian di atas, perspektif Barat tidak membawa aspek ketuhanan dalam mempengaruhi konsep kendiri. Sedangkan Islam melihat aspek ketuhanan memberi pengaruh terhadap pembentukan konsep kendiri. Perspektif Barat juga tidak 
mengemukakan jalan khusus yang dapat membantu untuk mengurangkan atau menangani konsep kendiri negatif. Namun begitu, menurut perspektif Islam dengan mengutamakan pandangan Allah SWT dapat membantu menangani keadaan tersebut. Konsep kendiri yang seimbang diutamakan dalam Islam untuk mengimbangi diri dari dipengaruhi unsur mazmumah iaitu sifat putus asa dan sifat ujub. Sifat putus asa terhasil daripada rasa kecewa atau penilaian yang terlalu negatif terhadap diri manakala sifat ujub terhasil apabila seseorang membuat penilaian yang terlalu tinggi terhadap kelebihan diri. Islam memandang keji kedua-dua sifat tersebut kerana kedua-duanya boleh mendorong manusia kepada perbuatan yang menyimpang. Oleh itu, dalam mencapai konsep kendiri positif, individu digalakkan mengutamakan penilaian atau pandangan Allah SWT untuk mendapat keredaan-Nya dengan sentiasa melakukan segala suruhan dan saranan-Nya dan mengelak diri dari mendekati apatah lagi melakukan segala larangan dan tegahan-Nya. Jika merasa lemah, Allah SWT menjadi tempat menaruh harapan. Manakala, jika merasa diri kuat atau berkuasa, pantas meletakkan nilai kehambaan pada diri dengan rasa syukur kerana segala pujian adalah milik Allah SWT dan Dia yang menganugerahkan kekuatan atau kekuasaan tersebut kepada hamba-Nya.

\section{Rujukan}

Abī 'Abd Allāh Muhammad bin Ismā'îl bin 'Ibrāhīm al-Bukhārī. Sah̄̄h Bukhārī, ed. Muhamad Abdul Qādir Ahmad 'Atō. Kāherah: Dār al-Taqwā li al-Turāth, 2001.

Al-Ghazali. dlm, Nor Anisah Abdul Malek, Konsep Manusia

Menurut Pandangan Islam. Kuala Lumpur: Arena Ilmu Sdn. Bhd., 1992.

Lilturath, 2000. Ihyā' 'Ulūm al-Dìn. Kāherah: Dār al-Taqwa . Kitāb al-Arbaīn fì Usūl al-Dīn, terj. Mohd. Suhail, 40

Prinsip Agama Penyucian Rohani Untuk Meraih Akhlak Terpuji. Batu Caves, Selangor, 2012.

Al-Jawziyyah, Ibn Qayyīm. Tuhfah al-Mawdūd bi Ahkām alMawlūd, tahq. 'Abdul al-Qādir al-Arnaud. Damaskus: Maktabah Dār al-Bayān, 1971. 
Al-Kindī. Al-Qawlu fī al-Islām, dlm, Dr. Muhammad 'Uthmān Najātī, Al-Dirāsāt al-Nafsānīyah 'Indi al- 'Ulamāa' al-Muslimīn. Beirut: Dār al-Shurūk, 1993.

Azizi Yahaya, Fawziah Yahya, Zurihanmi Zakaria \& Noordin Yahaya. Pembangunan Kendiri. Johor: UTM, 2005.

Burns, R. B. The Self Concept: Theory, Measurement, Development and Behaviour. New York: Longman, 1979.

Burns, R.B., Essential Psychology. Ed. ke-2. United Kingdom: Kluwer Academic Publishers, 1991.

Spielberger, C. D. Encyclopedia of Applied Psychology. USA: Imprint: Academic Press, 2004.

Cooley, C. H., Human Nature and the Social Order. New York: Scribners, 1902.

Engku Ahmad Zaki Engku Alwi. Membangun Modal Insan Melalui Pemantapan Akidah. Putrajaya: Jabatan Kemajuan Islam, 2007.

Epstein, S., "The Self-Concept Revisited or a Theory of a Theory," American Psychologist, (May 1973): 404-416.

Fariza Md Sham, Salasiah Hanin Hamjah \& Mohd. Jurairi Sharifudin, Personaliti dari Perspektif Al-Ghazali. Bangi: Fakulti Pengajian Islam, UKM, 2008.

Habibah Elias \& Noran Fauziah Yaakub. Psikologi Personaliti. Kuala Lumpur: Dewan Bahasa dan Pustaka, 2006.

Haron Din. Manusia dan Islam. Ed. ke-6. Kuala Lumpur: Dewan Bahasa Dan Pustaka, 2010.

Harun Din. Islam: Ada Apa Dengan Islam? Batu Caves: PTS Millennia Sdn. Bhd., 2007.-52.

Lecky, P., Self Consistency, dlm. Burns, R. B., The Self Concept: Theory, Measurement, Development and Behaviour. New York: Longman, 1979.

Mahmood Nazar Mohamed. Pengantar Psikologi: Satu Pengenalan Kepada Jiwa dan Tingkah Laku Manusia. Kuala Lumpur: Dewan Bahasa \& Pustaka, 2001.

Melati Sumari et al. Teori Kaunseling dan Psikoterapi. Kuala Lumpur: Penerbit Universiti Malaya, 2014.

Mohammad Salleh. Terapi Solat Tahajud. Kuala Lumpur: PTS Millennia Sdn.Bhd., 2008.

Mohd. Salleh Lebar. Asas Psikologi Perkembangan. Kuala Lumpur: Utusan Publication \& Distributors Sdn. Bhd, 1994. 
Mostafa Kamal Mokhtar. "Konsep Pembangunan Rohani Manusia: Kajian Perbandingan di antara Sufisme dan Psikologi,” Jurnal Psikologi Malaysia 15 (2001):1-20.

Muhammad Jamaluddin Al-Qasimi Ad-Dimasqi, Mutiara Ihya' Ulumuddin Hak Milik Muslim: Imam al-Ghazali, terj. Norzuzilawati et al. Selangor: Illusion Network, 2009.

Musa Fathullah Harun. Pengantar Tasawwuf Islam. Sungai Buloh: Dr.Musa Bin Fathullah Harun,1996.

Rogers, C. R., Client-centered Therapy. New York: Houghton Mifflin, 1951.

Rohany Nasir \& Fatimah Omar. "Burnout dan Konsep Kendiri Kerjaya di Kalangan Pegawai Kebajikan Masyarakat," ed. Rohany Nasir \& Fatimah Omar, Kesejahteraan Manusia: Perspektif Psikologi. Bangi: UKM, 2006.

Sayyid Quthb. Tafsīr fì Zhīlalīl Qur'ān di Bawah Naungan alQuran, terj, As'sd Yasin (Jakarta: Gema Insan Press, 2003.

Shavelson, R.J. \& Bolus, R. "Self-Concept: The Interplay of Theory and Method," Journal Of Educational Psychology 74, (1982): 3-17.

Șalih Aḥmad al-Shamī. Al-Muhazzibu min Ihyā' 'Ulūm al-Dīn.

Ed. ke-3 . Damsyik: Dār al-Qalam, 2010.

Wells, L. E., "Theories of Deviance and the Self-Concept," Social Psychology 41:3 (1978):184-204.

Yatimah Sarmani \& Mohd. Tajudin Ninggal. Teori Kaunseling Al-Ghazali. Batu Caves,Selangor: PTS Islamika, 2008). 